\title{
Mapping the Extent of Organic Matter Content, Soil Permeability Rate, Soil Structure and Textural Classes of Kersa Woreda, Jimma Zone, South Western Ethiopia
}

\author{
Tolossa Ameyu \\ Ethiopian Institute of Agricultural Research; Jimma Agricultural Research Center P.O Box 192, Jimma, Oromia, \\ Ethiopia
}

\begin{abstract}
Compatible soil databases are essential for establishing the current status of the earth's components and processes, and for monitoring rates of change in the status of these resources. This study was conducted with the objective of mapping and evaluation of the temporal and spatial distribution of soil organic matter content, structure, permeability and textural classes of kersa woreda. The spatial interpolation model showed that a good performance distribution of soil textural class, structure, permeability and organic matter content. The most dominant soil textural class of the study woreda is sandy loam. The permeability rate of study area is dominated by slow to moderate permeability rate. The maximum soil organic matter distribution of kersa woreda range from 3.94- 4.26 percent and the minimum soil organic matter distribution ranges from 2.98-3.316 percent. The major soil structural distribution of the study woreda is medium or coarse granular that cover all parts of the woreda except small area of the woreda.
\end{abstract}

Keywords: Mapping, Texture, Permeability and Organic matter

DOI: $10.7176 / \mathrm{JEES} / 10-12-02$

Publication date: December $31^{\text {st }} 2020$

\section{Introduction}

Soils are increasingly recognized as major contributors to ecosystem services in terrestrial environment (Palm et al., 2007). Services such as food production, prevention of land degradation, water quality and carbon sequestration, just to name a few, are provided by soils (Lal, 2004). The importance of these ecosystem services has increased the relevance of soils in the socio-political agenda, resulting in an increased need of worldwide soil information. Spatial resolutions of soil maps for most parts of the world are too low to help with practical land management (Sanchez et al., 2009). Other earth sciences (e.g., climatology, geology) have taken advantage of the digital revolution and data availability. However, the conventional soil mapping still delineates space mostly according to qualitative criteria and renders maps using a series of polygons, which limits resolution.

The need for higher resolution soil datasets was already recognized by soil scientists, particularly by the International Union of Soil Sciences (IUSS) working group on digital soil mapping when proposing the launch of the Global Soil Map (GSM) project (Hempel et al., 2014). The GSM projects aims at establishing standards for and eventually produce a global digital coverage of soil properties at $100 \mathrm{~m}$ resolution. The Global Soil Map provides the framework for supplying soil information in a format and resolution compatible with other fundamental data sets from remote sensing, terrain analysis, and other systems for mapping, monitoring, and forecasting biophysical processes (Arrouays et al., 2014).

Several studies determined the importance and effect of soil texture on soil organic matter (SOM), total organic matter (TOC) and moisture. Burke et al., (1990) found that soil clay content and total soil organic matter was positively correlated across large regions of the Great Plains. Soil texture have significant relation on SOM and TOC in many of decomposition models and organic matter formation (Rastetter et al., 1991; Raich et al.,1991). SOM is the soil nutrient pool and the changes will affect the quality and quantity of soil fertility. SOM stabilize soil $\mathrm{pH}$, which plays an important role in controlling the supply of nutrients and their availability for plant intake (Campbell et al., 1996). The level of SOM accumulation depends basically on tillage methods and residue management practices (Kong et al.,2009). Haas et al.(1957) reported that, about $42 \%$ average decrease in soil organic carbon (SOC) in the surface $15 \mathrm{~cm}$ of the soil after $30-40$ years of dry land crops across the Great Plain of the United States.

Concentrations and turnover of SOM is affected by the formation of a large number of factors, such as climate (Ganuza and Almendros, 2003), topography (Burke, 1999), vegetation (Finzi et al., 1998 ), the parent material (Spain, 1990) and management (Yang and Wander, 1999). Most studies recognized that climate, particularly temperature and precipitation, are the most important factor regulating SOM (Sims and Nielsen, 1986; Homann et al.,1995; Alvarez and Lavado, 1998). Seasonal factor determines a great extent of vegetation cover, quantity and quality of organic matters in soil, the rate of SOM mineralization and litter decomposition (Quideau et al.,2001; Heviaa et al.,2003). Jenny et al.(1949) showed that decomposition of organic compounds was related to climatic parameters. To date, the quantitative relationship between SOM and temperature and 
precipitation has been recognized (Callesen et al., 2003). In general, SOM is increases with precipitation and decreases with temperature (Burke et al., 1989; Ganuza and Almendros, 2003). Alvarez and Lavado (1998) also reported that SOM content in the $0-50 \mathrm{~cm}$ soil layer significantly related with the precipitation/temperature ratio.

However, the relationship between SOM and climate variables on a large scale is relatively weak, which makes it difficult to predict changes in the SOM as a function of projected climate change on the continental scale (Kern et al., 1998). To assess quantitatively the potential influence of climate change on SOM on a regional scale and/or global, it is important to identify the main factors regulating climate SOM, and to develop relationships among the main factors and SOM whole different scale of land and the area different.

The relationship between SOM/TOC and altitude has also been investigated and positive correlations were reported (Sims and Nielsen, 1986). Altitude also influences SOM/TOC by controlling soil water balance, soil erosion and geologic deposition processes (Tan et al., 2004).

Soil texture is determined by the percentage (by weight) of sand, silt, and clay particles in a soil sample. The size of a soil particle determines whether it is sand, silt, or clay. Soil Survey staff often record the percentage of rock fragments greater than $2 \mathrm{~mm}$ in diameter to accompany their description of soil texture. Generally speaking, clay rich soils are more than $40 \%$ clay particles, sandy soils are more than $55 \%$ sand, and loamy soils have percentages of sand, silt, and clay in the right proportions so that the influence of all particles is equal (Wildman and Gowans, 1978). Soil texture is an important property contributing to soil's erodibility. Soils with a high content of silt, very fine sand ( 0.05 to $0.10 \mathrm{~mm}$ in diameter), or expanding clay minerals tend to have high erodibility. Erodibility is low for clay-rich soils with a low shrink-swell capacity because these clay particles mass together into larger aggregates that resist detachment and transport.

Sandy soils with large amounts of fine, medium, or coarse sand particles ( 0.10 to $2.0 \mathrm{~mm}$ in diameter) also have low erodibility. Sand particles lack the ability to aggregate together, but because most sandy soils are highly permeable, water runoff is low, hence erosion is often slight. In addition, the large grain size of sandy soils means that it takes more energy to transport its particles than those of finer-textured soils. Medium-textured soils (loamy soils) tend to be most erodible because they have high amounts of silt and very fine sands. These soils tend to have moderate to low permeability and low resistance to particle detachment. If disaggregated, small particles (silts and clays) are easily transported. Rock fragments can also prevent erosion by protecting the soil from raindrop impact. This study was conducted with the objective of mapping and evaluation of the temporal and spatial distribution of soil organic matter content, structure, permeability and textural classes of kersa woreda.

\section{Material and Methods Description of the Study area}

The study was conducted at Kersa District in Jimma Zone, Oromia National Regional State, and south western Ethiopia. Kersa woreda is located at Latitude: $7^{\circ} 44^{\prime} 59.99^{\prime \prime}$ N Longitude: $37^{\circ} 04^{\prime} 60.00^{\prime \prime} \mathrm{E}$ with altitude ranging from 1740 to 2660 meters above sea level and $18 \mathrm{~km}$ East of Jimma. A survey of the land in this woreda shows that $58.6 \%$ is arable or cultivable (37.5\% was under annual crops), $17.3 \%$ pasture, $6.0 \%$ forest, and the remaining $18.9 \%$ is considered swampy, degraded or otherwise unusable (Government of Oromia Region (last accessed 1 August 2006). The climate of the Kersa woreda is characterized as hot humid tropical with bimodal heavy rainfall which is uniform in amount and distribution, ranging from 1200 to $2800 \mathrm{~mm}$ per year, with short and main seasons occurring from mid February to May and June to September, respectively. In normal years, the rainy season extends from mid February to early October. The mean annual temperature of the area is $19.5^{\circ} \mathrm{C}$. It is mostly known for its vegetation coverage suitability for coffee, crop, livestock and bee production. The soil type of the study area is characterized with black to red soils. 


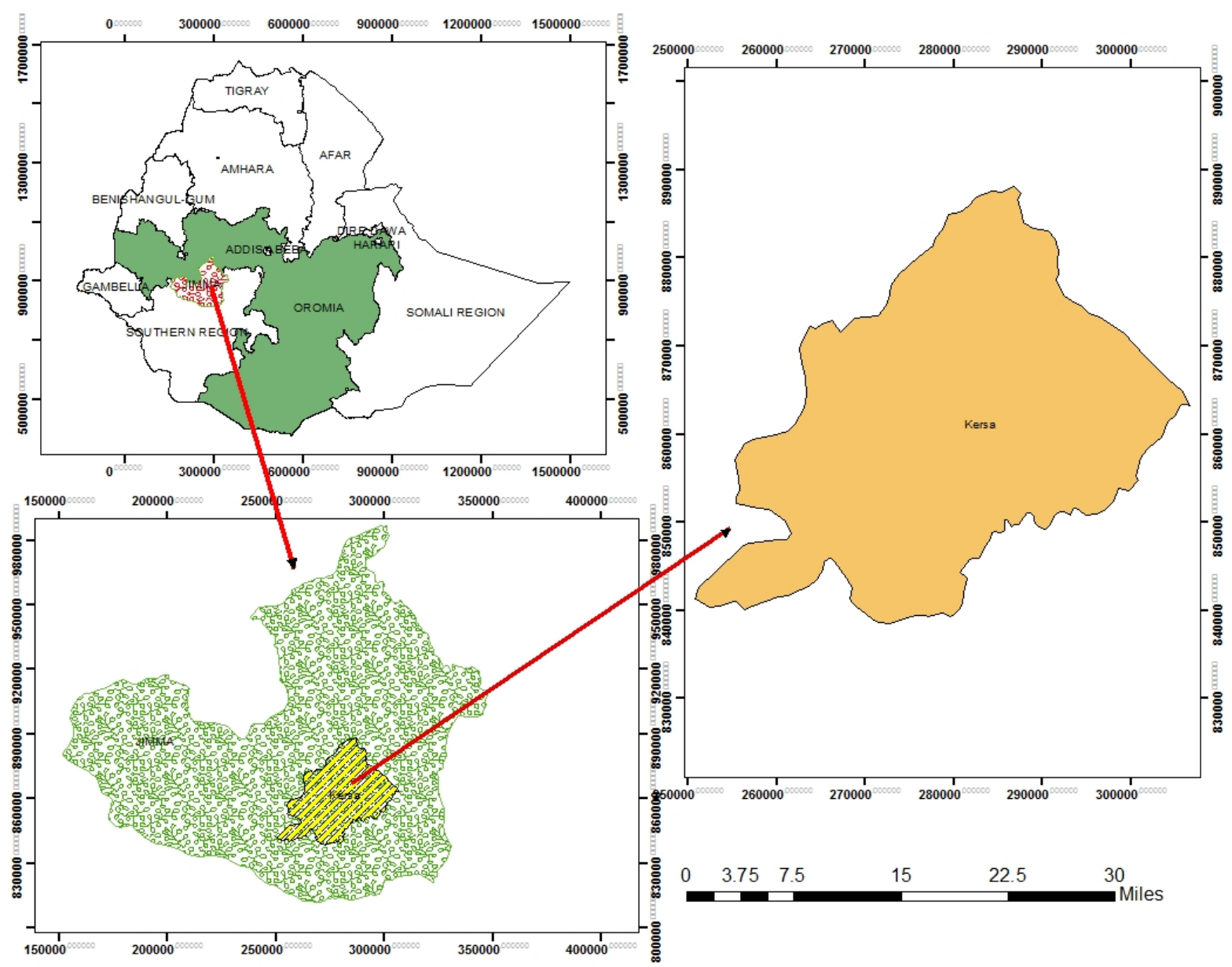

Figure 1.description of study area

\section{Soil sampling}

Fifty (50) Composite soil samples were collected from $30 \mathrm{~cm}$ depth using auger with its co-ordinate. The disturbed soil samples were air dried, sieved to pass through $2 \mathrm{~mm}$ sieve, and placed in a labeled plastic bag and transported to Jimma Agricultural Research Center soil and plant tissue laboratory for analysis and this disturbed composite soil samples were analyzed for particle size distribution (soil texture), which was done by Bouyoucos hydrometer method as described by Bouyoucos (1962). Organic matter was determined using wet oxidation as described by Black (1965). Using soil co-ordinate and soil result in ArcMap10.3 interpolation by "kriging" method spatial distribution of selected soil physical and chemical properties were mapped.

\section{Result and Discussion Soil Properties}

Soil particles (silt, sand and clay) and organic matter content distribution maps constructed using kriging interpolation method in Arc Map ${ }^{\circledR} 10.3$ are shown in Figure below. The map shows that northern and southern parts of study woreda have less silt content than eastern and western parts. Most of the area of the woreda has sand content below 30\% and clay content in north and south of study area is more than central parts. Also western parts have high organic matter content in comparison to the west. The average standard errors of the kriging interpolation maps were $0.94 \%, 1.53 \%, 1.36 \%$ and $0.18 \%$ for the silt, sand, clay and organic matter content percentage respectively. Sand textural distribution the woreda is ranging from medium to high sand textural distribution. Soil texture is an important property contributing to soil's erodibility. From this we understand that soils with a high content of silt, very fine sand ( 0.05 to $0.10 \mathrm{~mm}$ in diameter), or expanding clay minerals tend to have high erodibility. Erodibility is low for clay-rich soils with a low shrink-swell capacity because these clay particles mass together into larger aggregates that resist detachment and transport. The soil textural distribution of southern part of kersa woreda is highly dominated by sand textural class and some part of south western woreda is less sand textural class except some place of the woreda. 


\section{Spatial Distribution of Soil Textural class of Kersa woreda}
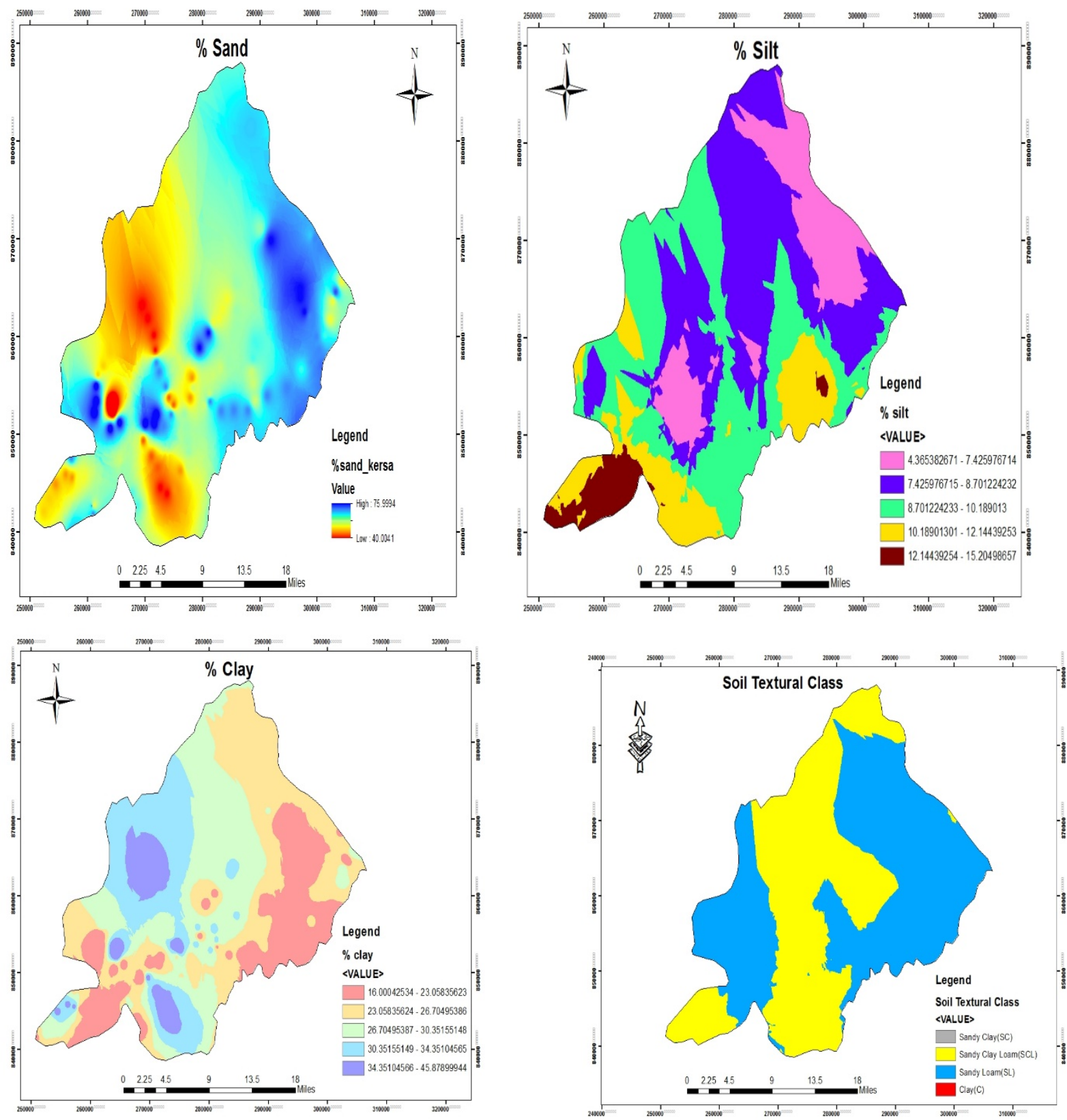

Figure 2.Top soil $(0-20 \mathrm{~cm})$ map of soil textural class \% distribution of kersa woreda

From the result of above map, kersa woreda is moderately dominated by silt soil textural class. In general the overall silt percentage of the woreda ranges from minimum of 4.3 upto maximum of 15.2. From this general percentage, the silt distribution of north eastern part of kersa woreda is less which is around 4.3 up to 7.4 percent. The silt distribution of the northern part to central part of the woreda is from 7.4 upto 8.7 percent. The north western, southern and some part of south eastern of the woreda is dominated with $8.2-10$ percent of silt distribution. South western and some area of the western part is10.18-12.14 percent of silt texture.

Generally from the study, the results shows that the most dominant soil textural class of the study woreda is sandy loam that distributed at eastern to south eastern and the western part of the kersa woreda and sandy clay loam is the second dominant soil textural class specifically at northern, central, southern and south western part of the study woreda. In addition to these textural classes very minimum amount of sand clay and clay was distributed in the woreda. According to the above map 23.05-26.7 of clay percentage was distributed at northern, north eastern and some part of south and south western of kersa woreda, and 26.7-30.35 of clay percentage was dominated at north to central part and some part of south and west of the woreda. 


\section{Spatial Distribution of Soil structure of kersa woreda}

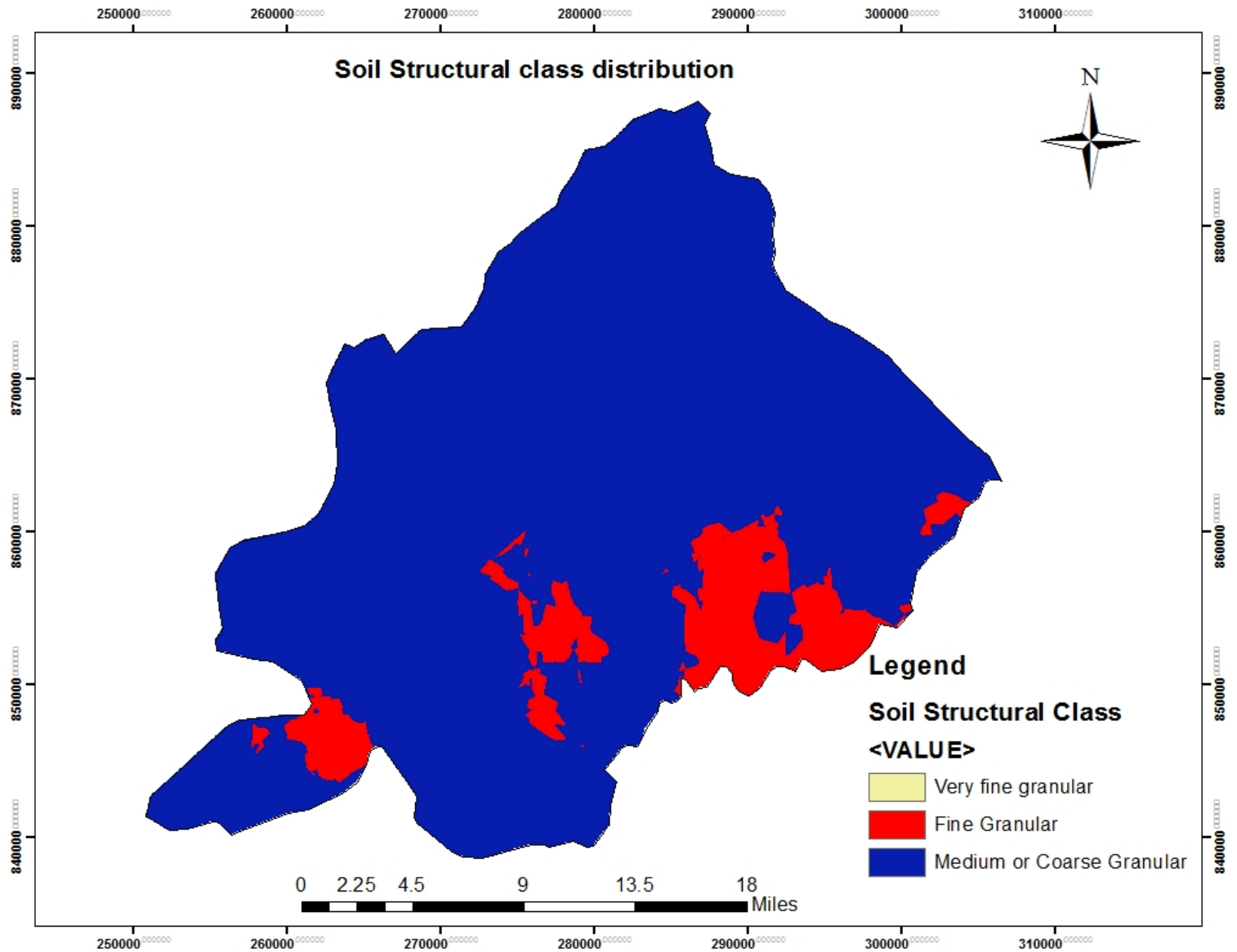

Figure 3.Top soil $(0-20 \mathrm{~cm})$ map of Soil structural distribution in kersa woreda

From the above soil structural distribution map the major soil structural distribution of the study woreda is medium or coarse granular that cover all parts of the woreda and a very minimum fine granular soil structure is found in some part of the woreda like south eastern and south western part of the study woreda, aswell as too minimal very fine soil granular structure was observed and as we have been discussed in the above soil textural class distribution of the study woreda the most part of the woreda is dominated by sandy loam and sandy clay loam, while soil structural distribution is medium or coarse granular and fine granular. This shows as the positive correlation of soil texture and soil structure. Generally kersa woreda is dominated by medium or granular structure followed by fine granular soil structure. 


\section{Spatial Distribution of soil organic matter of kersa woreda}

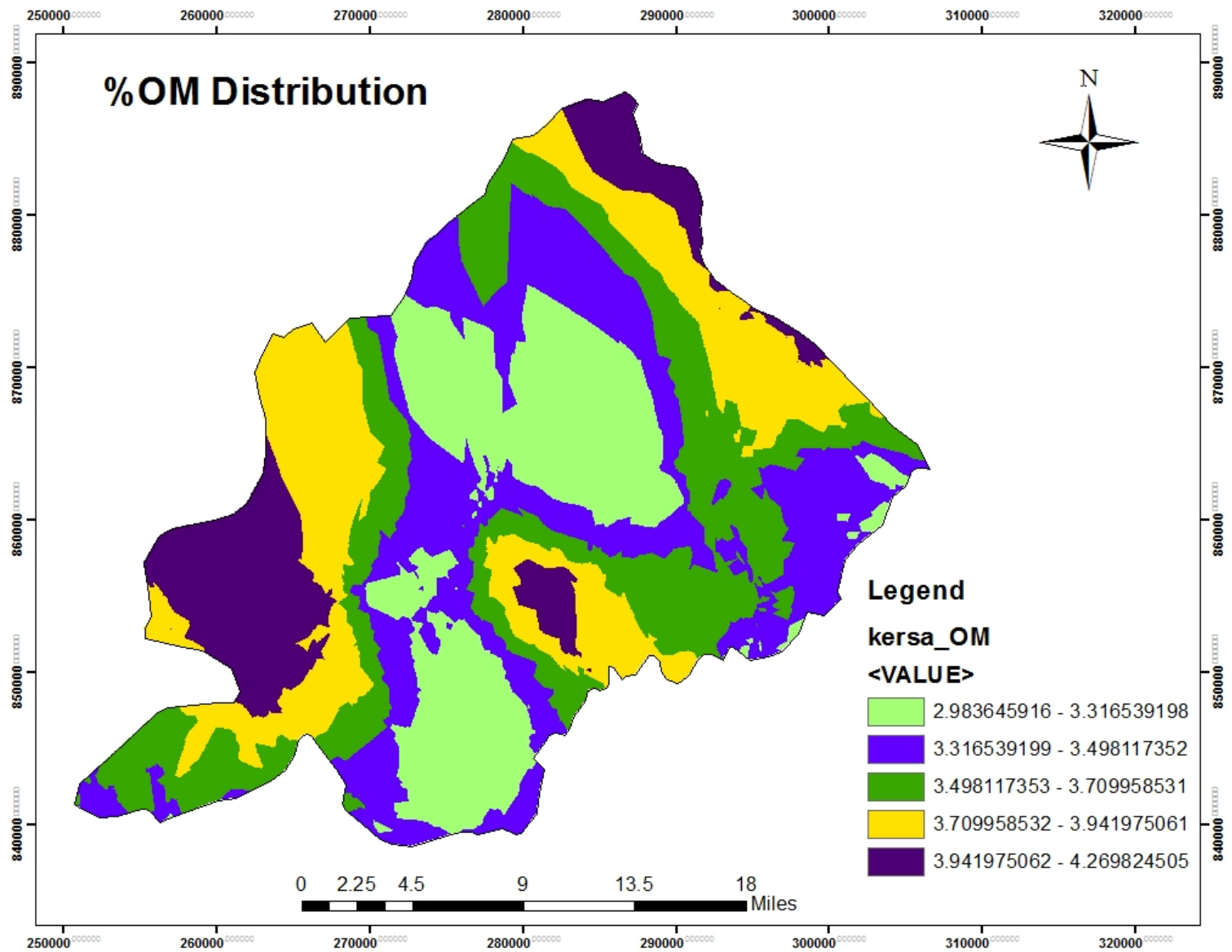

Figure 4 Top soil $(0-20 \mathrm{~cm})$ map soil organic matter percentage distribution

From the above soil organic matter distribution map of kersa woreda, the northern, north to east, western and small area of south east of the woreda is dominated by high soil organic matter content with the distribution range of 3.94-4.26 percent. And also the minimum soil organic matter distribution of the woreda includes:-southern, central and small area of eastern parts which ranges from 2.98-3.316 percent. Some part of eastern, central, southern, North West and small parts of south west of kersa woreda contains 3.316-3.498 percent of organic matter distribution. South eastern, north central and south west part contains 3.498-3.7 percent of soil organic matter distribution and 3.7-3.94 percent of organic matter distribution where obtained at north east, west and small parts of south east of the study woreda.

SOM is the soil nutrient pool and the changes will affect the quality and quantity of soil fertility. SOM stabilize soil $\mathrm{pH}$, which plays an important role in controlling the supply of nutrients and their availability for plant intake (Campbell et al., 1996).Burke et al., (1990) found that soil clay content and total soil organic matter was positively correlated across large regions of the Great Plains. Soil texture have significant relation on SOM and TOC in many of decomposition models and organic matter formation (Rastetter et al., 1991; Raich et al.,1991). Generally from the result obtained the woreda is dominated with medium to high organic matter content which is good indication for crop productions. 


\section{Soil Permeability determination}

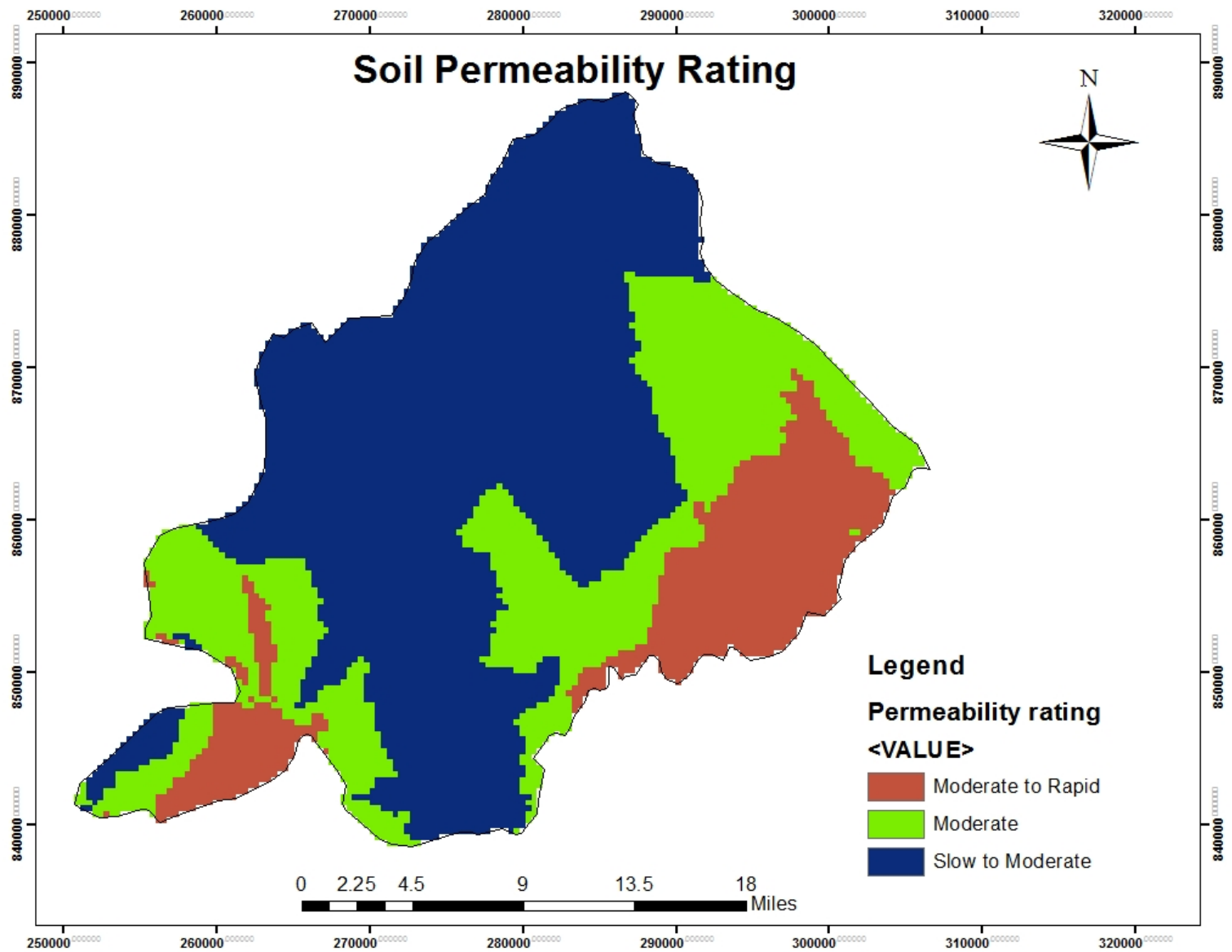

Figure 5.Soil permeability rating of kersa woreda

Permeability is the ease in which water, air, and plant roots move through the soil. It makes ease of air, water and root movement and also affects rate of water intake and drainage. As indicated or illustrated on the above map of permeability rate of the soil, the major area of woreda, specifically northern,central,southern and small area of south west of the study woreda have slow to moderate permeability rate. The eastern and small parts of central and western has moderate permeability rate. Finally some south to west and south to east area of the woreda shows moderate to rapid permeability, these results may be due to the textural class of soil or due to the soil structure of the study soil. Soil Structure affects soil permeability, porosity and root growth. Topsoil textural class is an important criterion in the SMW for further characterization of the dominant soil of a soil association or mapping unit (FAO, 1995). Generally the permeability rate study area is dominated by slow to moderate followed by moderate permeability rate.

\section{Summary and Conclusions}

The three layers of soil texture (clay, silt and sand), organic matter content, soil structure and permeability of soil of Kersa woreda were mapped. The spatial interpolation model showed that a good performance distribution of soil textural class, structure, permeability and organic matter content. The most dominant soil textural class of the study woreda is sandy loam, and sandy clay loam is the second dominant soil textural class of the woreda. The permeability rate of study area is dominated by slow to moderate followed by moderate and moderate to rapid permeability rate. The maximum soil organic matter distribution map of kersa woreda range from 3.94-4.26 percent and the minimum soil organic matter distribution ranges from 2.98-3.316 percent. The major soil structural distribution of the study woreda is medium or coarse granular that cover all parts of the woreda except small area of the woreda. The study also proposed the possible use of the physical properties data sets and their derived products. The data availability is a corner stone for modelers who have no access to high spatial resolution data.

\section{References}

Alvarez, R., R.S. Lavado, 1998. Climate, organic matter and clay content relationships in the Pampa and Chaco soils, Argentina. Geoderma., 83: 127-141.

Arrouays, D., Grundy, M.G., Hartemink, A.E., Hempel, J.W., Heuvelink, G.B.M., Hong, S.Y.,Lagacherie, P., 
Lelyk, G., McBratney, A.B., McKenzie, N.J., Mendonca-Santos, M.d.L.,Minasny, B., Montanarella, L., Odeh, I.O.A., Sanchez, P.A., Thompson, J.A., Zhang, G.-L.,2014.Chapter Three Global Soil Map: Toward a FineResolution Global Grid of Soil Properties. In: Sparks, Donald L. (Ed.), Advances in Agronomy. Academic Press, pp. 93-134.

Batjes, N.H. and Bridges, E.M., 1994. Potential emissions of radioactively active gases from soil to atmosphere with special reference to methane: development of a global database (WISE). Journal of Geophysical Research, 99(D8): 16479-16489.

Batjes, N.H., 1997. A world data set of derived soil properties by FAO-UNESCO soil unit for global modeling. Soil Use and Management, 13: 9-16.

Baumgardner, M.F., 1999. Soil data bases. In: M.E. Sumner (Editor), Handbook of Soil Science. CRC Press, Boca Ratton, pp. H: 1-40.

Burke, I.C., C.M. Yonker, W.J. Parton, C.V. Cole, K. Flach, D.S. Schimel, 1989. Texture, climate, and cultivation effects on soil organic matter content in US grassland soils. Soil Science Society of America Journal., 53: 800-805.

Burke, I.C., D.S. Schimel, C.M. Yonker, W.J. Parton, L.A. Joyce, W.K. Lauenroth, 1990. Regional modeling of grassland biogeochemistry using GIS. Landscape Ecology., 4: 45-54.

Burke, I.C., 1999. Spatial variability of soil properties in the short grass steppe: the relative importance of topography, grazing, microsite, and plant species in controlling spatial patterns. Ecosystems., 2: $422-438$.

Callesen, I., J. Liski, K. Raulund-Rasmussen, 2003.Soil carbon stores in Nordic well-drained forest soilsrelationships with climate and texture class.Global Change Biology., 9: 358-370.

Campbell, C.A., B.G. McConkey, R.P. Zentner, F. Selles, D. Curtin, 1996. Tillage and crop rotation effects on soil organic $\mathrm{C}$ and $\mathrm{N}$ in a coarse-textured typic Haploboroll in southwestern Saskatchewan. Soil Tillage Res., 37: 3-14.

FAO, 1995. Digital Soil Map of the World and Derived Soil Properties. Food and Agriculture Organization of the United Nations, FAO.

FAO-UNESCO, 1974-1981. Soil Map of the World, 1:5,000,000. Vol. 1 to 10. United Nations Educational, Scientific, and Cultural Organization, Paris.

Finzi, A.C., N.V. Breemen, C.D. Canham, 1998. Canopy tree soil interactions within temperate forests: tree species effects on carbon and nitrogen. Ecological Applications., 8: 440-446.

Fischer, G., Van Velthuizen, H.T. and Nachtergaele, F.O., 2000. Global Agro-ecological Zones Assessment: Methodology and results. IR-00-064, Food and Agriculture Organization of the United Nations (FAO) and International Institute for Applied Systems Analysis (IIASA), Laxenburg.

Fischer, G., Van Velthuizen, H.T. and Prieler, S., 2001. Assessment of potential productivity of tree species in China, Mongolia and the Former Soviet Union: Methodology and Results. IR-01-015, International Institute for Applied Systems Analysis (IIASA), Laxenburg.

Ganuza, A., G. Almendros, 2003. Organic carbon storage in soils of the Basque Country (Spain): the effect of climate, vegetation type and edaphic variables. Biology and Fertility of Soils., 37: 154-162.

Haas, H.J., C.E. Evans, E.F. Miles, 1957. Nitrogen and carbon changes in Great Plains soils as influenced by cropping and soil treatments. USDA Tech. Bull, vol. 1164. U.S. Gov. Printing Office, Washington, DC.

Hempel, J.W., McBratney, A.B., Arrouays, D., McKenzie, N.J., Hartemink, A.E., 2014.GlobalSoilMap project history. Glob. Basis Glob. Spat. Soil Inf. Syst. 3.

Heviaa, G.G., D.E. Buschiazzoa, E.N. Heppera, 2003.Organic matter in size fractions of soils of the semiarid Argentina. Effects of climate, soil texture and management. Geoderma., 116: 265- 277.

Homann, P.S., P. Sollins, H.N. Chappell, A.G. Stangenberger, 1995. Soil organic carbon in a mountainous, forested region: relation to site characteristics. Soil Science Society of America Journal., 59: 14681475.

Jenny, H., S.P. Gessel, F.T. Bingham, 1949. Comparative study of decomposition of organic matter in temperate and tropical regions. Soil Science., 68: 419-432.

Kern, J.S., D.P. Turner, R.F. Dodson, 1998. Spatial patterns in soil organic carbon pool size in the northwestern United States.In: Lal, R. (Ed.), Soil Processes and the Carbon Cycle. Lewis Publishers, Boca Raton, FL, pp: 29- 43.

Kong, X.B., T.H. Dao, J. Qin, H. Qin, C. Li, F. Zhang, 2009. Effects of soil texture and land use interactions on organic carbon in soils in North China cities' urban fringe. Geoderma., 154: 86-92.

Lal, R., 2004.Soil Carbon Sequestration Impacts on Global Climate Change and Food Security. Science 304, $1623-1627$.

Nachtergaele, F.O., 1999. From the Soil Map of the World to the Digital Global Soil and Terrain Database: 19602002. In: M.E. Sumner (Editor), Handbook of Soil Science. CRC Press, Boca Raton, pp. H5-17.

Palm, C., Sanchez, P., Ahamed, S., Awiti, A., 2007. Soils: A Contemporary Perspective. Annu.Rev.Environ.Resour.32,99-129. http://dx.doi.org/10.1146/annurev.energy.31.020105.100307. 
Quideau, S.A., Q.A. Chadwick, A. Benesi, R.C. Graham, M.A. Anderson, 2001. A direct link between forest vegetation type and soil organic matter composition. Geoderma., 104: 41-60.

Raich, J.W., E.B. Rastetter, J.M. Melillo, D.W. Kicklighter, P.A. Steudler, B.J. Peterson, A.L. Grace, B. Moore III, C.J. VoÈroÈsmarty, 1991. Potential net primary productivity in South America: Application of a global model. Ecological Applications., 1: 399-429.

Rastetter, E.B., M.G. Ryan, G.R. Shaver, J.M. Melillo, K.J. Nadelhoffer, J.E. Hobbie, J.D. Aber, 1991. A general biogeochemistry model describing the responses of the $\mathrm{C}$ and $\mathrm{N}$ cycles in terrestrial ecosystems to changes in CO2, climate and $\mathrm{N}$ deposition. Tree Physiology, 9: 101-126.

Sanchez, P.A., Ahamed, S., Carré, F., Hartemink, A.E., Hempel, J., Huising, J., Lagacherie, P.McBratney, A.B., McKenzie, N.J., Mendonça-Santos, M. de L., Minasny, B.,Montanarella, L., Okoth, P., Palm, C.A., Sachs, J.D., Shepherd, K.D., Vågen, T.-G.,Vanlauwe, B., Walsh, M.G., Winowiecki, L.A., Zhang, G.-L., 2009.Digital Soil Map of the World. Science 325, 680-681.

Sims, Z.R., G.A. Nielsen, 1986. Organic carbon in Montana soils as related to clay content and climate. Soil Science Society of America Journal, 50: 1269- 1271.

Spain, A.V., 1990. Influence of environmental conditions and some soil chemical properties on the carbon and nitrogen contents of soil tropical Australian rainforest soils. Australian Journal of Soil Research, 28: $825-839$.

Tan, Z.X., R. Lal, N.E. Smeck, F.G. Calhoun, 2004.Relationships between surface soil organic carbon pool and site variables. Geoderma., 121: 185-187.

Webb, S.R., Rosenzweig, C.E. and Levine, E.R., 1991. A global data set of soil particle size properties. Technical Memorandum 4286, NASA, New York.

Yang, X.M., M.M. Wander, 1999. Tillage effects on soil organic carbon distribution and storage in a silt loam soil in Illinois. Soil and Tillage Research., 52: $1-9$.

Zobler, L., 1986. A world soil files for global climate modeling. Technical Memorandum 87802, NASA Goddard Institute for Space Studies (GISS), New York, NY. 